\section{Inequality: American Exceptionalism or Global Trend?}

\author{
Andrew Knox \\ Senior, Political Science/Philosophy
}

Has the precipitous rise in inequality in the United States since the 1970s been a primarily American phenomenon, or is it simply the most extreme example of a larger international trend? The authors in this syllabus have emphasized the uniqueness of American inequality - in part to draw attention to the importance of national policy, in part as a rhetorical appeal that inequality is not a necessary fact of modern life, and in part to argue against explanations that attribute rising inequality to skills-based technological change (SBTC) or "globalization." According to Hacker and Pierson, the rise of inequality "has been substantially more meteoric in the United States than in other rich nations... The hyperconcentration of income in the United States... sets the United States apart from other rich nations, calling into serious doubt the usual explanation for America's winner-take-all economy, SBTC."1 Therefore, American politics is to blame for rising inequality, not transnational economic or political trends. Increases in inequality in other nations, especially the Anglo-Saxon countries, they attribute to economic competition with, and interconnection to the U.S. Also, "these [English-speaking] nations have also generally emulated U.S. public policy more than other nations have." But what is distinctly American about the policies that they refer to? Similar policies were pursued in Chile and the U.K. ${ }^{2}$ during or before the period Hacker and Pierson emphasize, the late 1970s into the 1980s. David Harvey refers to Chile as "the exemplar of 'pure' neoliberal practices after 1975". 3 Following the 1973 coup d'état against the socialist government of Salvador Allende, Chile embarked on an extensive campaign of privatization, deregulation and cuts in overall state spending, ${ }^{4}$ which greatly increased inequality in an already very unequal country. ${ }^{5}$ While in a much more radical and dictatorial form, these policies were very similar to those described by Hacker, Pierson and Bartels.

Does Hacker and Pierson's explanation of American inequality hold? Is the United States the exception, or simply the most extreme case of a general economic trend? In this paper I will examine trends in inequality across five other countries: the United Kingdom, Sweden, Germany, Japan and Russia. I select these countries because of their political and economic similarities to the United States. With the exception of Sweden, they are all members of the G8. ${ }^{6}$ While Russia is somewhat of an outlier as the only country that is not a liberal democracy, I include it because of its economic similarity to the United States as an advanced industrial/post-industrial nation and its experience of "shock therapy" in the 1990s. During this period, the Russian economy was transformed virtually overnight from a Communist planned economy to a free market capitalist economy, resulting in a rapid increase in both inequality and poverty. ${ }^{7}$ Privatization of state assets, deregulation, and cuts in social spending proceeded at a pace to put "Reaganism at warp speed" to shame. As in Chile, the policies Hacker and Pierson identify as having created the American winner-take-all 
economy were implemented much more quickly and fundamentally than in the U.S.

Testing Hacker and Pierson's thesis is important to understanding inequality because it allows us to understand the causes of rising inequality. If inequality is on the rise not just in the U.S., but also in my five case studies, then something other than the American political system is to blame. This would not necessarily mean that policy is irrelevant; if all of the case studies implemented "winner-take-all" economic policies, then I would have to conclude, with Hacker and Pierson, that rising inequality is driven by policy, and not by structural changes in the world economy. The major caveat, however, would be that policy-driven inequality is a global phenomenon not particular to the United States.

\section{Background: Global inequality}

Before analyzing trends in inequality in specific countries, I want to first examine global inequality. While global inequality may tell us little about inequality in individual countries or even regions, it gives us some idea about inequality outside the United States. As of 2014, U.S. GDP was $16.14 \%$ of world GDP, slightly behind China $(16.32 \%) .{ }^{8}$ While the U.S. may be an economic powerhouse, its share of the world's GDP makes it unlikely that world inequality would be greatly skewed by even a highly unequal United States. The American portion of world GDP has been shrinking as the country has become more inegalitarian, as well. ${ }^{9}$

\section{Aggregate world inequality}

Global inequality has been rising since the Industrial Revolution. ${ }^{10}$ Considered in terms of the Gini coefficient, global inequality ranks at around 70 , or 0.700 - staggeringly high, given that actually existing societies have never exceeded the low 60s. Brazil, one of the most inegalitarian countries in the world, has a Gini coefficient of 57. ${ }^{11}$ From 2005 to 2011, global inequality fell slightly, although we should be wary of concluding that a centuries-long trend is ending on the basis of six years of data. ${ }^{12}$ According to Piketty's data, global wealth inequality has risen slowly but steadily from 1987 to $2013 .{ }^{13}$

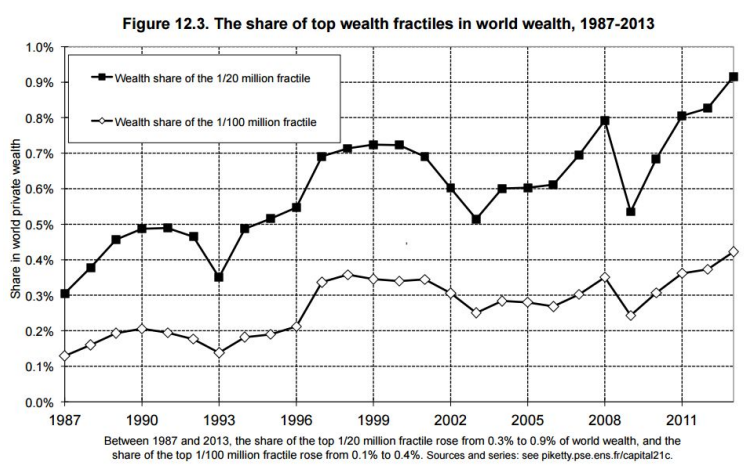

Milanovic, on the other hand, is more optimistic, although he admits that a sustained decrease in global inequality would be an unprecedented reversal. ${ }^{14}$

\section{Inequality Between Regions}

Not only is global inequality increasing, the gap between the poorest and the richest regions has increased dramatically in the past century. The 1999 United Nations Human Development Report compared the fifth of the world's people living in the highest income countries to the fifth living in the lowest income countries: the income gap between these two regions was 3 to 1 in 1820,11 to 1 in 1913, 30 to 1 in 1960, and 74 to 1 in $1997 .{ }^{15}$ In terms of GDP, the ratio was $86 \%$ of world GDP for the highest income fifth, compared to just 
$1 \%$ of world GDP for the lowest income fifth. ${ }^{16}$ Given these trends analyzed by Piketty, these inequalities are almost certainly larger than they were in the 1990s. While poverty has decreased in very poor regions like Sub-Saharan Africa or Southeast Asia, ${ }^{17}$ vast inequality between the poorest and richest regions still remains.

\section{The United Kingdom}

It would be difficult to imagine a better natural experiment to test the role of policy: another industrialized liberal democracy with deep cultural and political similarities to the United States, pursuing, sometimes even consciously, similar policies to United States, virtually at the same time. Of all the countries I examine, patterns of inequality in the United Kingdom have been most similar to those in the United States. Inequality in the U.K. actually increased at a higher rate from the 1980s to the 2010s than inequality in the U.S., thought U.S. inequality was higher to begin with. ${ }^{18}$ It is not coincidental that British politics and American politics mirrored each other as did British inequality and American inequality. The similarity between the policy agendas of Reagan/Thatcher and Clinton/Blair is striking. Under the banner of "rolling back the welfare state," both Reagan and Thatcher successfully confronted organized labor, cut social spending, and cut taxes significantly for the very rich. ${ }^{19}$ Both of their successors from their respective center-left rival parties (Clinton/Blair) continued these policies. ${ }^{20}$ Clinton and Blair, like Reagan and Thatcher, quite consciously saw themselves as part of one international political project, the "Third Way". ${ }^{21}$ And what were the results? As I cited before, a seven-point increase in the U.K.'s
Gini coefficient in three decades. While seven points may not sound like much, remember that the gap between the most unequal and the most equal societies to ever exist is only about 35 Gini points.

\section{Germany}

Because of its division into the Communist East and capitalist West until 1990, Germany is somewhat problematic as a case study. Because of this, I will focus on the post-reunification period - to the extent that I can, given that some datasets begin in the 1980s. As of 2011, Germany had a Gini coefficient of 30.1, about ten points lower than Britain or the United States. ${ }^{22}$ Its Gini score has increased by 4.5 points since the mid-1980s, with most of the increase occurring from the mid-1990s to late 2000s ${ }^{23}$ What explains this relatively small increase in inequality? Public cash transfers are significantly more redistributive in Germany than the U.S. ${ }^{24}$ West Germany had a strong union tradition, which successfully resisted Reagan/Thatcher-style reforms in the 1980s. ${ }^{25}$ In the East, the transition from Communism to capitalism was significantly more gradual and less plagued by corruption than its Russian counterpart ${ }^{26}-$ more on this later.

\section{Sweden}

Of all European countries, Sweden had one of the strongest traditions of social democratic politics, ${ }^{27}$ and for much of the $20^{\text {th }}$ century enjoyed low inequality. ${ }^{28}$ However, beginning in the 1980s, the Swedish social-democratic consensus began to erode. As in the United States, the banking system was deregulated and taxes cut for the very wealthy. ${ }^{29}$ Much like the American Democratic 
Party, once they returned to power in 1994, the Social Democrats had shifted their economic policy to that of their nominal adversary, the Conservatives. Instead of full employment and "solidaristic" wage policy, they emphasized "deficit reduction, inflation control, and balanced budgets." " Inequality began to rise during the 1980s. ${ }^{31}$ The trends of wealth inequality in Britain and Sweden are remarkably similar: very high and gradually rising from 1810 to 1910 , declining sharply from 1910 to 1970 , then rising again from 1970 to $2010 .^{32}$
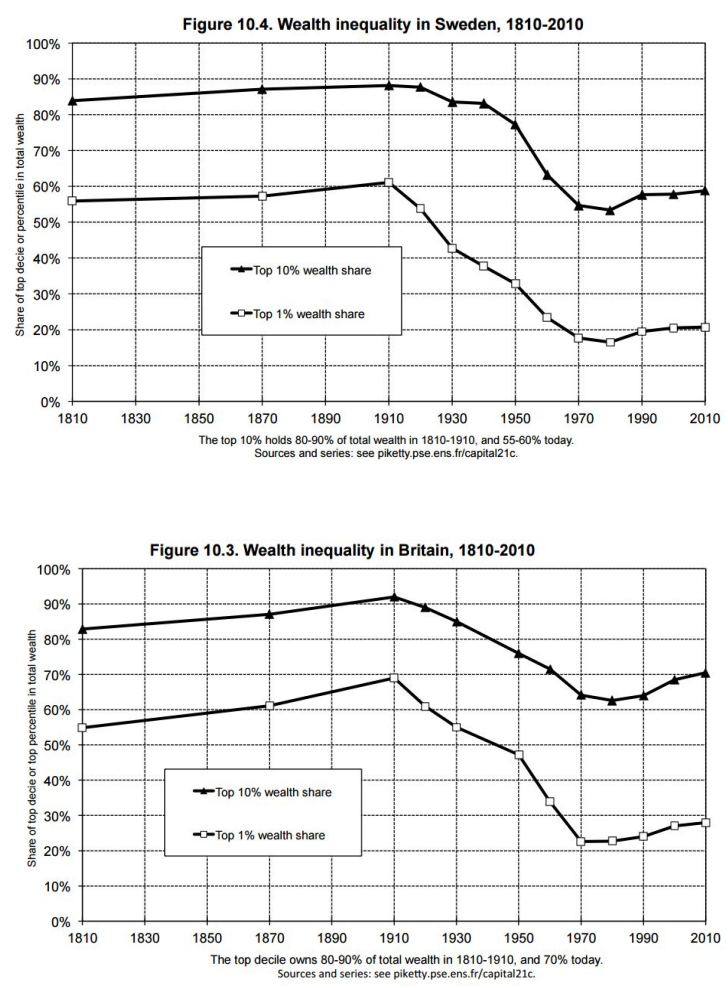

\section{Russia}

As measured by the Gini coefficient, the Russian Federation is slightly more unequal than the United States, with a Gini coefficient of 0.416 in 2012, compared to 0.411 for the United States in 2013. ${ }^{33}$ Despite the obviously unequal nature of the Soviet system, in which the nomenklatura enjoyed social privileges unknown to the vast majority, inequality increased greatly since the dissolution of the Soviet Union in $1991 .{ }^{34}$ In 1980, the USSR's Gini coefficient was 0.290 ; in 1990, 0.281. ${ }^{35}$ This is an incredible increase: 13.5 Gini points in less than twenty-five years. Indeed, Russian inequality is far more exceptional than American inequality, which increased by less than ten Gini points in the same time period (see footnote 19). ${ }^{36}$ What explains this? There was no correspondingly dramatic change in the Russian economy over this relatively brief time period - for example, a crash in world oil prices. Also, inequality fell or remained stable throughout the $1980 \mathrm{~s},{ }^{37}$ making it implausible to attribute the post-1990 spike in inequality to a previously existing economic trend. The elephant in the room, of course, is the transition from a Communist planned economy to a market economy. Unlike in East Germany or some of the other ex-communist countries, the transition was rapid and extreme, referred to as "shock therapy" by its supporters and opponents alike. Reddaway and Glinski compare shock therapy to Bolshevism - both were "determined and ruthless attempts to implement one or another set of prescriptions deduced from abstract theories in Russia via revolution from above." 38 While in a radically dissimilar political context, the economic principles that inspired shock therapy were the same as those of Reagan and Thatcher. ${ }^{39}$ And as in the United States and the U.K., the primary economic beneficiaries of the rollback of the state were the very rich, not the average consumer or taxpayer, as the reformers claimed. Deregulation of prices, deep cuts in social spending, privatization of state-owned firms, and tax incentives for large corporations all contributed to the rise of the Russian 
"oligarchs", many of them former members of the nomenklatura itself. ${ }^{40}$

\section{Japan}

Japan experienced a low level of inequality during the post-WWII period due to its reformed tax structure and occupational laws, high levels of growth, and the income-compressing effects of the war. ${ }^{41}$ This aligns with Piketty's attribution of much of the low inequality of the $20^{\text {th }}$ century to the economic and physical destruction of the World Wars, which obviously disrupted the accumulation of capital and individual wealth. ${ }^{42}$ Since the postwar period, levels of inequality in the country have remained stable. ${ }^{43}$ Why? Moriguchi and Saez argue that "the postwar reforms transformed the one-time measures into lasting ones, facilitating a structural change in the Japanese economy that likely prevented re-concentration of income in subsequent decades". While the war led to major income compression in Germany, the U.K. and even the United States, none of these countries experienced the kind of socioeconomic reforms implemented under the Allied occupation. These included sweeping land reform, "eliminating virtually all largeand medium-sized landowners." ${ }^{44}$ However, even this view has been challenged by some, including economist Toshiaki Tachibanaki, who argues that the perceived egalitarian Japan is simply a "myth," and that income inequality is on the rise. ${ }^{45}$

\section{Conclusions}

Plainly, inequality has increased substantially even outside the English-speaking nations. Looking beyond my five case studies, the same trend appears, with inequality on the rise throughout the OECD, and the state's ability or willingness to offset it declining. ${ }^{46}$

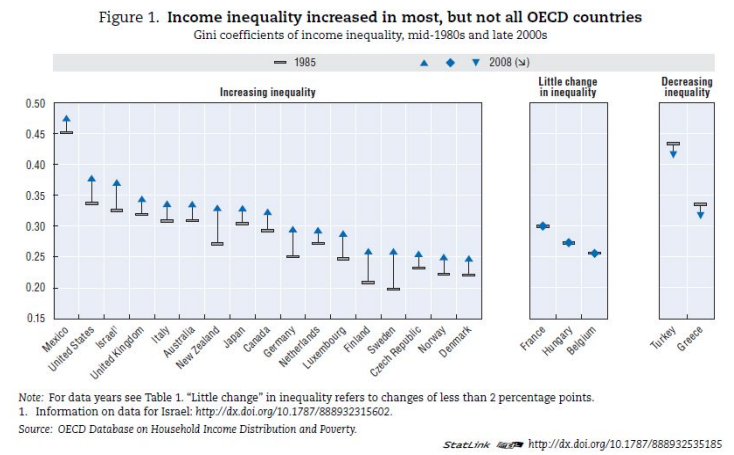

This conclusion is in line with Piketty, who against Simon Kuznets argues that "there is no natural, spontaneous process to prevent destabilizing, inegalitarian forces from prevailing permanently," ${ }^{47}$ and advocates a global tax on capital to prevent inequality from reaching socially destabilizing levels. ${ }^{48}$ "The consequences for the long-term dynamics of the wealth distribution are potentially terrifying," he concludes. ${ }^{49}$

However, this does not discount the importance of national policy - far from it. Rising inequality is better understood as an outcome of the global spread of neoliberal economic policies, rather than an American pathology, occasionally spilling over into the other English-speaking countries. Each of my case studies where inequality increased significantly adopted neoliberal economic policies similar to those adopted by the U.S. in the 1980s and ' 90 s, and inequality increased more when they were implemented more vigorously, as in the United States, Russia or the United Kingdom. What do I mean by neoliberal? Harvey defines neoliberalism as "a theory of political economic practices that 
proposes that human well-being can best be advanced by liberating individual entrepreneurial freedoms and skills within an institutional framework characterized by strong private property rights, free markets, and free trade. ${ }^{\circ 50}$ Neoliberalism demands low taxation, low social spending, privatization of state assets, and deregulation. Since the 1970s, neoliberalism has become the political and economic orthodoxy of much of the world, "the most successful ideology in world history," in Perry Anderson's words. "51 "Embedded liberalism" and social democracy, once the consensus in Europe and the United States, have all but disappeared from the mainstream, even from the historical parties of the center-left (the Democrats in the U.S., Labour in the U.K., the German SPD, etc.) This is the larger story Hacker and Pierson are missing: the rise of "winner-take-all politics" globally.

\section{Endnotes}

1. Hacker and Pierson 38-40.

2. Wapshott 126-7. British Prime Minister Margaret Thatcher sent Ronald Reagan a congratulatory letter on the day of his inauguration. Shortly after, she visited Washington, an opportunity Democrats took advantage of "to point to the industrial turmoil in Britain caused by Thatcher's imposition of a strict monetarist economic policy, with its attendant redundancies and bankruptcies. They would use the British example as a stick with which to beat the new president's low taxation, low public spending economic policies."

3. Harvey 74 .

4. Valdés 21-24. The "Chicago boys" who advised Pinochet's economic program would go on to inspire much of Reagan and Thatcher's policy agenda.

5. Klein 86.

6. Harvey 66.

7. Milanovic (2011) 10. "After the breakup of the Soviet Union in the early 1990s, inequality in Russia increased at a speed never recorded before anywhere." For poverty, see "Study Finds Poverty Deepening in Former Communist Countries," New York Times, October 12 2000.

8. "GDP as Share of World GDP at PPP By Country" 9. Ibid. In 1989 , U.S. GDP was $22.28 \%$ of world GDP; in $2004,19.64 \%$.
10. Milanovic (2011) 11.

11. Ibid 10.

12. Ibid 11.

13. Piketty $430-43$.

14. Milanovic 11.

15. U.N. Human Development Report 1999, 3.

16. Ibid.

17. Simmons, "Sub-Saharan Africa makes progress against poverty but has long way to go," Pew Research Center.

18. Milanovic 8. From the 1980 s to 2011 , "inequality in the United States increased from about 35 to 40 or more Gini points (see Chart 1), and in the United Kingdom, from 30 to about 37 Gini points."

19. Harvey 58-61, Piketty 98.

20. Harvey 63.

21. Atkins, "The Third Way International," Jacobin.

22. World Bank database.

23. OECD 45.

24. Ibid 36.

25. Harvey 89.

26. Wiesenthan 2-3. "Has shock therapy been introduced in East Germany? The answer is a definite no. Only two of the five substantial [shock therapy] measures, namely the unfreezing of prices and cutting of subsidies were introduced at the start of economic and monetary union on July 1, 1990."

27. Erixon 3, Harvey 112. The Swedish Social Democrats governed continuously from 1932 to 1976 , forming coalition governments during only nine of those years.

28. Piketty 344.

29. Harvey 114-5.

30. Ibid.

31. Piketty 344-5. “....inequality in Sweden has increased significantly since 1980-1990 (and in 2010 was just slightly lower than in France)."

32. Ibid.

33. World Bank database.

34. Reddaway \& Glinski 302, Stiglitz 2.

35. Alexeev \& Gaddy 29. Because these measures are based on legal income and ignore the underground economy, they probably underestimate inequality slightly.

36. Milanovic (1998) 40. In the ex-communist countries, inequality increased by "on average, $1 \frac{1}{2}$ Gini points per year, a rise that is almost three times as fast as the rise recorded in those Western countries where inequality rose most rapidly in the 1980s: United Kingdom, the Netherlands, and United States."

37. Alexeev \& Gaddy 29. By 1985, the Soviet Gini coefficient had fallen to 0.284 , increasing slightly to 0.290 in 1988, then falling again to a low of 0.275 in 1989.

38. Reddaway \& Glinski 10.

39. Ibid 269. 
40. Klein 230-1.

41. Moriguchi and Saez 1-3.

42. Piketty 20.

43. Moriguchi and Saez 28. "While the top $1 \%$ wage income share in Japan has been nearly constant at around 5\% from 1970 to 2000, the share in the United States has risen exponentially from $5 \%$ to $12 \%$ during the same period."

44. Ibid 19.

45. Ibid 5.

46. OECD 22-3. "The latest trends in the 2000s showed a widening gap between rich and poor not only in some of the already high inequality countries like Israel and the United States, but also - for the first time - in traditionally low-inequality countries, such as Germany, Denmark, and Sweden (and other Nordic countries), where inequality grew more than anywhere else in the 2000 s... Finally, income taxes and cash transfers became less effective in reducing high levels of market income inequality in half of OECD countries, particularly during the late 1990s and early 2000s." The fact that, of all economically advanced countries, Israel has a similarly high level of inequality seems to substantially undermine Hacker and Pierson's Anglo-Saxon hypothesis.

47. Piketty 21.

48. Ibid 515-27.

49. Ibid 571.

50. Harvey 2.

51. Anderson, "Renewals," New Left Review.

\section{Works Cited}

"Study Finds Poverty Deepening in Former Communist Countries," New York Times, October

12, 2000, accessed April 21, 2016, http://www.nytimes.com/2000/10/12/world/stu dy-finds-

poverty-deepening- in-former-

communist-countries.html

Alexeev, Michael V. and Clifford G. Gaddy. "Income Distribution in the U.S.S.R. in the 1980s,"

Review of Income and Wealth Series 39, Number 1 (March 1993), accessed April 21, 2016, http://www.roiw.org/1993/23.pdf
Anderson, Perry. "Renewals." New Left Review 1 (January/February 2000).

Atkins, Curtis. "The Third Way International." Jacobin 20 (Winter 2016).

Erixson, Lennart. "A Swedish Economic Policy - The Theory, Application and Validity of the Rehn-Meidner Model," in Gösta Rehn and the Swedish Model at Home and Abroad, ed. E. Wadensjö and H. Milner), Ashgate Ltd (Spring 2001).

http://www2.ne.su.se/paper/wp00_13.pdf

Hacker, Jacob S. and Paul Pierson.

Winner-Take-All Politics: How Washington

Made the Rich Richer-and Turned Its Back on the Middle Class. New York: Simon \&amp;

Schuster, 2010.

Harvey, David. A Brief History of

Neoliberalism. Oxford: Oxford University

Press, 2005.

Klein, Naomi. The Shock Doctrine: The Rise of Disaster Capitalism. New York: Penguin, 2008.

Milanovic, Branko. "More or Less.” Finance and Development Volume 48, No. 3

(September

2011).

https://www.imf.org/external/pubs/ft/fandd/201 1/09/pdf/milanovi.pdf

Ibid. Income, Inequality and Poverty during the Transition from Planned to Market Economy. Washington: The World Bank, 1998.

Moriguchi, Chiaki and Emmanuel Saez. "The Evolution of Income Concentration in Japan, 1886-2002: Evidence from Income Tax Statistics.” NBER Working Paper No. 12558 (October 2006). 
Organization for Economic Co-operation and Development (OECD). "An Overview of Growing

Income Inequalities in OECD Countries: Main Findings," in Divided We Stand: Why Inequality

Keeps Rising. OECD Publishing, 2011. http://www.oecd.org/els/soc/49499779.pdf

Piketty, Thomas. Capital in the Twenty-First Century. Translated by Arthur Goldhammer. Cambridge: Harvard University Press, 2014.

Reddaway, Peter and Dmitri Glinski. The Tragedy of Russia's Reforms: Market Bolshevism Against Democracy. Washington: United States Institute of Peace Press, 2001.

Simmons, Kaitie. "Sub-Saharan Africa makes progress against poverty but has long way to go,"

Pew Research Center, September 24, 2015, accessed April 25, 2016, http://www.pewresearch.org/fact-tank/2015/09/ 24/sub- saharan-africa- makes-progressagainst-

poverty-but- has-long- way-to- go/

Stiglitz, Joseph. "Development Based on Participation - A Strategy for Transforming Societies,"

Transition 9, no. 6 (December 1998).

United Nations Development Programme (UNDP). "Human Development Report 1999." Oxford: Oxford University Press, 1999. http://hdr.undp.org/sites/default/files/reports/26 $\underline{0 / \text { hdr } 1999 \text { en nostats.pdf }}$

Valdés, Juan Gabriel. Pinochet's Economists:

The Chicago School in Chile. Cambridge:

Cambridge University Press, 1995.

Wapshott, Nicholas. Ronald Reagan and Margaret Thatcher: A Political Marriage. New York:
Sentinel, 2007.

Wiesenthal, Helmut. "East Germany as a Unique Case of Societal Transformation: Main Characteristics and Emergent Misconceptions" (paper presented at the annual meeting for the 16th IPSA World Congress, August 21-25, 1994).

World Bank, Development Research Group. "GINI Index." http://data.worldbank.org/indicator/SI.POV.GI $\mathrm{NI} /$ countries/ 